\title{
Peningkatkan Hasil Belajar Sains Konsep Listrik Dinamis melalui Penerapan Model Pembelajaran Generatif pada Siswa Kelas VI SD Negeri 53 Sawerigading Kota Palopo
}

\author{
Hasnah HP \\ SD Negeri 53 Sawerigading, Kota Palopo \\ +62 821-8942-5699
}

\begin{abstract}
Abstrak
Penelitian ini merupakan penelitian tindakan kelas yang bertujuan untuk mengetahui peningkatan hasil belajar sains konsep perubahan lingkungan pada siswa kelas VI SD Negeri 53 Sawerigading Kota Palopo, yang diajar melalui penerapan model pembelajaran generatif. Penenlitian ini terdiri atas dua siklus yaitu siklus I dan II masing-masing terdiri tiga kali pertemuan. Subjek penenlitian ini adalah siswa kelas VI SD Negeri 53 Sawerigading Kota Palopo. Hasil penelitian menunjuakan bahwa ada peningkatan pembelajaran, baik pada aktivitas guru dan siswa maupun hasil tes siswa. Peningkatan ini dapat dilihat dari setiap siklus. Dimana pada siklus pertama 64,85 dan siswa yang tuntas belajar 22 orang (62,86\%). Pada siklus kedua 81,14 dan siswa yang tuntas 30 orang $(85,71)$. Disamping itu, data hasil observasi disetiap siklus menujukkan adanya perubahan sikap siswa kearah yang lebih positif, keaktifan dalam belajar, kerjasama dan keaktifan dalam menerima pelajaran. Dari hasil analisis tersebut dapat disimpulkan bahwa penerapan model pembelejaran generatif dapat meningkatkan hasil belajar sains pada siswa kelas VI SD Negeri 53 Sawerigading Kota Palopo. Dari hasil penelitian ini disarankan kepada guru SD untuk dapat menjadikan model pembelajaran generatif sebagai salah satu alternatif pendekatan pembelajaran dalam mengajarkan sains khususnya listrik dinamis di sekolah.
\end{abstract}

Kata Kunci: hasil belajar sains, konsep listrik dinamis, model pembelajaran generatif

\section{Pendahuluan}

Dalam upaya mendukung peningkatan kualitas pendidikan yang lebih baik dan berkualitas, dunia pendidikan mulai melakukan pembaharuan-pembaharuan pada sistem pendidikan nasional dengan menerapkan perubahan kurikulum. Kurikulum ini menuntut dominasi siswa dalam mencapai prestasi belajarnya dalam menempatkan siswa sebagai pusat pembalajaran atau "student centered" serta memposisikan guru sebagai fasilitator dan motivator dalam pembelajaran. Selain itu, konsep belajar yang berakar pada siswa dan konsep pembelajaran berakar pada guru. Sehingga dalam dunia pendidikan sasaran utama dari pengembangan pendidikan adalah transfer ilmu pendidikan dan teknologi. Guru dalam transfer ilmu pengetahuan memilih metode mengajar yang dapat memberikan kontribusi yang positif terhadap hasil belajar sains sehingga proses pembelajran yang terjadi di sekolah-sekolah berlansung secara efektif (Mulyasa, 2006).

Bidang studi sains merupakan salah satu mata pelajaran yang dianggap sulit dimengerti, membosankan dianggap mata pembalajaran yang tidak menarik oleh sebagian besar siswa. Hal ini disebabkan karena umumnya guru melakukan proses belajar mengajar di kelas 
menggunakan metode mengajar yang tidak bervariasi, hanya menerapkan model pengajaran yang masih menggunakan konsep-konsep pengajaran yang sesuai dengan buku teks, akibatnya siswa hanya mengikuti proses belajar mengajar saja di dalam kelas tanpa memahami materi yang diberikan guru.

Merujuk pada rendahnya hasil belajar sains di sekolah, guru tak henti-hentinya mencari jalan untuk meningkatkan hasil belajar siswa tersebut dengan memperbaiki sarana dan prasarana belajar, serta cara mengajar khususnya dalam bidang studi sains. Karena mata pelajaran sains merupakan salah satu bidang yang memegang peranan penting dalam mencapai tujuan pendidikan secara umum.

\section{Model Pembelajaran Generatif}

Model pembelajaran generatif (generative learning model) pertama kali diperkenalkan oleh Osborne dan Cosgrove (Sutarman dalam Made Wena, 2009: 177). Pembelajaran generatif terdiri atas empat, yaitu pendahuluan atau tahap eskplorasi; pemfokusan; tantangan atau tahap pengenalan konsep; dan penerapan konsep.

Tahap pertama yaitu pendahuluan/eksplorasi. Pada tahap ini guru membimbing siswa untuk melakukan eksplorasi terhadap pengetahuan, ide, atau konsepsi awal yang diperoleh dari pembelajaran pada tingkat kelas sebelumnya. Untuk mendorong siswa agar mampu melakukan eksplorasi guru dapat memberikan stimulus berupa beberapa aktivitas/tugas-tugas seperti melalui penelusuran atau demonstrasi terhadap suatu permasalahan yang dapat menunjukkan data dan fakta yang terkait dengan konsepsi yang akan dipelajari. Dalam aktivitas ini, gejala, data, dan fakta yang didemonstrasikan sebaiknya dapat merangsang siswa untuk berpikir kritis, mengkaji fakta, data, gejala, serta memusatkan pikiran terhadap permasalahan yang akan dipecahkan. Sehingga, dapat menumbuhkan rasa ingin tahu pada diri siswa. Melalui aktivitas demonstrasi / penelusuran, siswa didorong untuk mengamati gejala dan fakta. Kemudian guru mendorong siswa untuk melakukan diskusi tentang gejala atau fakta yang diamati atau diselidiki. Guru harus mengarahkan proses diskusi guna mengindentifikasi konsepsi siswa yang selanjutnya dikembangkan menjadi rumusan, dugaan sementara atau hipotesis. Dan guru memberikan makna, menyalahkan atau membenarkan terhadap konsepsi siswa (Sutarman dalam Asep Jihad, 2009: 178)

Tahap kedua adalah tahap pemfokusan atau intervensi. Pada tahap pemfokusan siswa melakukan pengajuan hipotesis melalui kegiatan laboratorium atau model pembelajaran lainnya. Pada tahap ini guru bertugas sebagai fasilitator yang menyangkut kebutuhan sumber, memberi bimbingan dan arahan, dengan demikian siswa melakukan proses sains. Dalam tahap ini siswa dilatih untuk bekerja sama dengan teman kelompok, membantu teman kelompok, menghargai pendapat teman, tukar pengalaman (sharing idea), dan keberanian bertanya. Dalam kegiatan ini, dapat berlatih lebih banyak tentang keterampilan laboratorium, berlatih, semua komponen proses sains yang mulai dari mengamati (observasi) mengukur, mengendalikan variabel, menggolongkan, membuat grafik, menyimpulkan, memprediksi, dan mengkomunikasikan.

Tahap ketiga adalah tahap tantangan atau tahap pengenalan konsep. Setelah siswa memperoleh data, selanjutnya menyimpulkan dan menulis dalam lembar kerja. Pada siswa diminta mempresentasekan temuannya melalui diskusi kelas. Melalui diskusi kelas akan terjadi proses tukar pengalaman diantara siswa. Dalam tahap ini, siswa berlatih untuk berani mengeluarkan pendapat teman, dan menghargai adanya perbedaan diantara pendapat teman. Pada proses diskusi berlangsung, guru bertindak sebagai fasilitator agar jalannya diskusi lebih 
terarah. Dan diakhiri diskusi, siswa memperoleh kesimpulan dan pemantapan konsep yang benar. Pada tahap ini pula, guru memantapkan konsep dan memberikan latihan soal. Latihan soal dimaksudkan agar siswa memahami secara mantap konsep tersebut. Pemberian soal latihan dimulai dari yang paling mudah kemudian menuju yang sukar (Swasono dalam Asep Jihad, 2009: 180). Dengan soal-soal yang kesukarannya rendah, sebagian besar siswa akan mampu menyelesaikan dengan benar. Sebaliknya, jika langsung diberikan soal yang tingkat kesukarannya tinngi, maka sebagan besar siswa tidak akan menyelesaikan soal dengan benar. Karena tidak mampu menyelesaikan soal dengan benar maka akan dapat menurungkan motivasi belajar siswa yang berakibat pada rendahnya hasil belajar.

Tahap keeempat adalah tahap penerapan. Pada tahap ini, siswa diajak untuk dapat memecahkan masalah dengan menggunakan konsep barunya atau konsep benar dalam situasi baru yang berkaitan dengan hal-hal praktis dalam kehidupan sehari-hari. Pada tahap ini siswa perlu diberikan banyaka latihan soal. Dengan latihan soal ini, siswa akan semakin memahami konsep (isi pembelajaran) secara lebih mendalam dan bermakna.

Berdasarkan hal tersebut di atas, maka penulis terinspirasi memilih metode generatif yang bertujuan untuk meningkatkan hasil belajar siswa pada pelajaran sains dalam menerapkan metode generatif, metode ini merupakan suatu cara untuk mengembangkan cara belajar siswa aktif. Dengan menggunakan metode ini siswa di harapkan memiliki pengetahuan, kemampuan serta keterampilan untuk mengkontruksi / membangun pengetahuan sains secara mandiri. Dengan pengetahuan awal (prior knowledge) yang telah dimiliki sebelumnya dan menghubungkan dengan konsep yang dipelajari, sehingga siswa dapat mengkonstruksi pengetahuan yang baru (Made Wena, 2009: 183).

Penerapan metode generatif dalam pembelajaran sains di kelas, siswa diajak untuk bersifat aktif dan mampu menyelesaikan masalah-masalah dengan konsep-konsep barunya yang berkaitan dengan kehidupan sehari-hari. Selain itu, guru memberikan bimbingan kepada siswa dan siswa yang mengutarakan pendapat-pendapat tentang materi yang diberikan, sehingga tercipta suatu kesimpulan tentang materi atau konsep yang dipelajari.

Bedasarkan latar belakang yang telah di uraikan di atas, maka pertanyaan yang menjadi pusat perhatian dalam penelitian ini adalah "Apakah hasil belajar sains konsep perubahan lingkungan dapat di tingkatkan melalui penerapan model pembelajaran generatif pada siswa kelas VI SD Negeri 53 Sawerigading Kota Palopo?"

\section{Metode Penelitian}

Penelitian ini merupakan penelitian tindakan kelas (classroom action research) dan cara pelaksanaannya meliputi 4 (empat) tahap, yaitu perencanaan, tindakan, observasi, dan refleksi. Penelitian ini berfokus pada du afaktor, yaitu faktor hasil belajar siswa setelah diterapkan model pembelajaran generative; dan faktor keaktifan siswa dalam mengikuti pelajaran dan terjadinya interaksi antara guru dan siswa serta siswa dengan siswa.

Lokasi penelitian ini adalah SD Negeri 53 Sawerigading Kota Palopo. Subjek penelitian ini adalah siswa kelas VI SD Negeri 53 Sawrigading Kota Palopo sebanyak 30 siswa dengan perincian 18 orang laki-laki dan 12 orang perempuan.

Penelitian tindakan kelas ini terdiri atas dua siklus, dimana kedua siklus tersebut merupakan rangkaian yang saling berkaitan. Pelaksanaan siklus II merupakan lanjutan dan pelaksanaan siklus I. 


\section{Siklus I}

\section{Tahap Perencanaan}

Pada tahap ini, langkah-langkah yang diikutkan adalah;

1. Menelaah materi pelajaran ilmu pengetahuan alam (sains) kelas VI SD

2. Menyusun rencana pembelajaran untuk setiap pertemuan (Lampiran I)

3. Membuat pedoman observasi untuk merekam proses pembelajaran di kelas (Lampiran 2)

4. Mempersiapkan soal-soal yang dijadikan tugas untuk diselesaikan secara kelompok individu (Lampiran 2)

5. Membuat alat evaluasi untuk melihat kemampuan siswa dalam menyelesaikan soal-soal yang berdasarkan materi yang diberikan (Lampiran 4).

\section{Tahap Tindakan}

Tindakan yang dilaksanakan secara operasional dijabarkan sebagai berikut:

1. Pada pertemuan pertama diadakan tes awal (pretest), unutk mengukur tingkat kemampuan siswa sebelum model pemebelajaran generative.

2. Menjelaskan kepada siswa cara pembelajaran dengan menerapkan model pembelajaran generatif.

3. Siswa diberi tugas atau soal latihan dan disesuaikan secara kelompok oleh masing-masing kelompok.

4. Selama proses belajar kelompok berlangsung setiap kelompok tetap diawali, dikontrol, dan diarahkan, serta diberi bimbingan seacra langsung pada kelompok yang mengalami kesulitan.

5. Hasil kelompok yang diperoleh didiskusikan atau setiap kelompok mempresentasikan ide melalui diskusi. Dari diskusi tersebut, siswa dapat menarik kesimpulan tentang konsep yang dipelajari.

\section{Tahap Obesrvasi}

Pada tahap ini dilaksanakan observasi terhadap plaksanaan tindakan dengan menggunakan lembar observasi yang telah dibuat, yaitu guru mencatat semua kejadian yang dianggap penting baik mengenal kegiatan siswa perorangan maupun dalam kerja kelompok tanggapan yang diberikan siswa tentang pendekatan yang digunakan yang penting akan menjadi acuan untuk melaksanakan tindakan

\section{Tahap Refleksi}

Merefleksikan setiap hasil yang diperoleh lembar observasi menilai dan mempelajari hasil perkembangan siswa pada siklus I dan kedua hasil inilah yang selanjutnya dijadikan acuan bagi peneliti untuk merancang perbaikan dan penyempurnaan pada siklus berikutnya (Siklus II) sehingga hasil yang dicapai lebih baik dari siklus sebelumnya (Siklus I).

\section{Siklus II}

Pada dasarnya kegiatan yang dilakukan pada siklus ini adalah mengulangi kembali tahaptahap yang dilakukan pada siklus sebelumnya. Disamping itu, dilakukan juga sejumlah rencana baru untuk memperbaiki atau merancang tindakan baru sesuai dengan pengalaman dan hasil reaksi yang diperoleh pada siklus I. 


\section{Tahap Perencanaan}

1. Melanjutkan tahap perencanaan yang telah dilakukan pada siklus I

2. Dan hasil refleksi pada siklus I guru menyusun rencana baru untuk ditindak lanjuti antara lain mengawasi siswa lebih ketat dan member arahan atau motivasi kepada siswa yang kurang memperhatikan pelajaran atau tidak aktif.

3. Anggota kelompok diacak dengan tetap memperhatikan heterogenitas kelompok, serta member informasi kepada siswa agar lebih bersemangat lagi untuk belajar sasins seacara kelompok

\section{Tahap Tindakan}

Tindakan siklus II adalah hamper sama dengan tindakan pada siklus I hanya melanjutkan langkah-langkah yang telah dilakukan pada siklus I dan beberapa yang dianggap perlu dalam memecahkan masalah yang muncul pada siklus sebelumnya. Tindakan yang dilakukan adalah:

1. Menjelaskan langkah-langkah penerapan model pembelajaran generative.

2. Kelompok yang mengalami kesulitan dalam menyelesaikan tugas deberikan bimbingan secara langsung dan seskali diarahkan secara klasikal. Demikianlah pula halnya dengan tugas yang dikerjakan secara individual.

3. Lembar jawaban dan masing-masing kelompok dan individu dikorelasi dan dibetulkan kemudian dikembalikan untuk menjadi bahan diskusi. Kemudian soal-soal yang dianggap perlu penjelasan /lebih lanjut, maka dibahas secara klasikal mengenai penyelesaian soal tersebut.

\section{Tahap Obesrvasi}

Tahap observasi siklus II ini adalah melanjutkan kegiatan pada siklus yang dilaksanakan pada saat proses belajar mengajar.

\section{Tahap Refleksi}

Pada tahap refleksi umumnya langkah-langkah yang dilakukan pada sillus II seperti halnya yang dilakuakan pada siklus I, yaitu:

1. Menilai dan mengamati perkembangan hasil belajar siswa tiap kelompok dan hasil belajar individu serta nilai akhir tes siklus II.

2. Mengamati dan mencatat perkembangan-perkembangan atau hal-hal yang dialami oleh siswa selama berlangsungnya proses belajar mengajar serta pada saat belajar mengajar.

3. Memberikan kesempatan kepada siswa untuk memberikan tanggapan atau saran-saran melalui tes/wawancara dan tulisan.

\section{Teknik Pengumpulan dan Analisis Data}

Data yang dikumpulkan yaitu data tentang perubahan sikap, kehadiran, keaktifan siswa dalam mengikuti kegiatan belajar diambil dengan cara pengamatan dan observasi. Selain itu juga dikumpulkan data mengenai hasil belajar sains siswa diambil tes setiap akhir siklus II, tes setiap siklus ini dibuat oleh penulis bekerjasama dengan guru bidang studi sains yang mengajar dalam kelas tersebut.

Data yang diperoleh akan dianalisis secara kualitatif dan kuantitatif yaitu data hasil observasi dianalisis secar kualitatif; dan data hasil tes dianalisis secara kuantitatif. Untuk jenis data kualitatif data dilakukan adalah kategorisasi. Kategorisasi skor yang digunaka nadalah criteria ini digunakan untuk menentukan kategori skor adalah lima. 


\section{Indikator Keberhasilan}

Indikator keberhasilan penelitian ini adalah apabila tes hasil belajar siswa sudah menunjukkan peningkatan jumlah siswa yang tuntas belajar. Menurut ketentuan Depdiknas siswa dikatakan tuntas belajar apabila memperoleh skor minimal $65 \%$ dan skor ideal dari tuntas klasikal apabila 85\% dari siswa telah tuntas belajar individual.

\section{Hasil Penelitian}

\section{Hasil Belajar Siswa Pada Siklus I}

Berdasarkan hasil analisis deskriptif sebagaimana yang tercantum pada lampiran, maka rangkuman statistik skor hasil belajar siswa kelas VI SD Negeri 53 Sawerigading Kota Palopo dapat dilihat pada tabel berikut:

Tabel 1. Statistik Skor Hasil Belajar Sains Siswa Pada Siklus I

\begin{tabular}{llr}
\hline No & Statistik & Nilai Statistik \\
\hline 1. & Subjek penelitian & 30,00 \\
2. & Skor maksimum & 85,00 \\
3. & Skor minimum & 50,00 \\
4. & Rentang skor & 35,00 \\
\hline Skor rata-rata & 64,85 \\
\hline
\end{tabular}

Apabila skor hasil belajar sains siswa pada siklus I dikelompokkan ke dalam 5 kategori maka diperoleh tabel distribusi frekuensi skor yang ditunjukkan pada tabel berikut:

Tabel 2. Distribusi Frekuensi dan Persentase Skor Hasil Belajar Sains Siswa Pada Siklus I

\begin{tabular}{rrrl}
\hline Skor & Frekuensi & Persentase & Kategori \\
\hline $0-54$ & 8 & $22,85 \%$ & Sangat rendah \\
$55-64$ & 5 & $14,29 \%$ & Rendah \\
$65-79$ & 15 & $42,86 \%$ & Sedang \\
$80-89$ & 7 & $20,00 \%$ & Tinggi \\
$90-100$ & 0 & $0,00 \%$ & Sangat tinggi \\
\hline
\end{tabular}

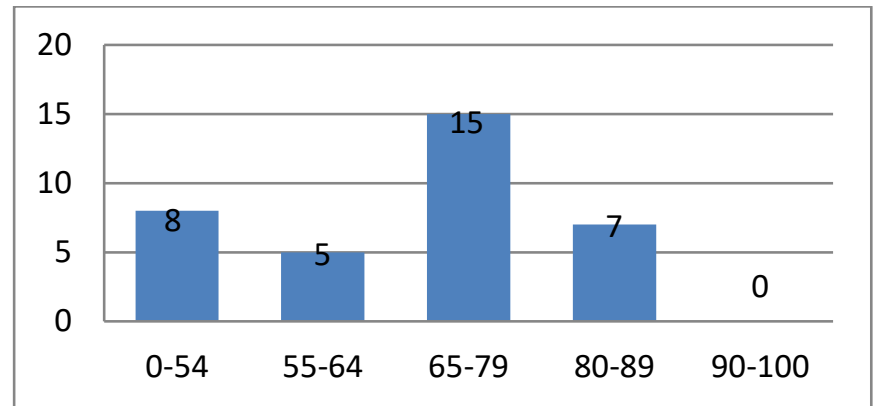

Gambar 1. Diagram Skor Hasil Belajar Siswa Siklus I

Dari tabel 2 dan gambar 1 menunjukkan bahwa hasil belajar sains konsep perubahan lingkungan pada siswa cukup bervariasi, dan terlihat bahwa masih ada siswa yang berada pada kategori sangat rendah, yaitu 8 orang atau 22,85\% kategori rendah 5 orang atau 14,29\%, kategori sedang 15 orang atau 42,86\%, kategori tinggi 7 orang atau $20 \%$ dan kategori sangat tinggi tidak ada. Hal ini disebabkan karena masih kurangnya antusias siswa, persentase kehadiran yang kurang dan proses pembelajaran yang didominasi oleh siswa yang pintar saja. 
Berdasarkan gambar 1 , tabel 1 dan table 2 dapat disimpulkan bahwa hasil belajar sains siswa kelas VI SD Negeri 53 Sawerigading Kota Palopo setelah dilakukan pembelajaran melalui metode generatif pada siklus I berada dalam kategori "sedang" dengan skor rata-rata 64,85, skor maksimum 85 dan skor minimum 50, dengan kata lain siswa kelas VI SD Negeri 53 Sawerigading Kota Palopo berada dalam kategori "sedang".

\section{Hasil Belajar Siswa Pada Siklus II}

Dari analisis skor hasil belajar sains siswa kelas VI SD Negeri 53 Sawerigading Kota Palopo setelah diterapkan model pembelajaran generatif selama siklus II dapat dilihat pada tabel berikut.

Tabel 3. Statistik Skor Hasil Belajar Sains Siswa Pada Siklus II

\begin{tabular}{llr}
\hline No & Statistik & Nilai Statistik \\
\hline 1. & Subjek penelitian & 35,00 \\
2. & Skor maksimum & 100,00 \\
3. & Skor minimum & 60,00 \\
4. & Rentang skor & 40,00 \\
\hline Skor rata-rata & 81,14 \\
\hline
\end{tabular}

Dari skor hasil belajar sains siswa yang tertera pada tabel 3 di atas, jika dikelompokkan ke dalam kategori tabel distribusi frekuensi skor seperti tabel berikut:

Tabel 4. Distribusi Frekuensi dan Persentase Skor Hasil Belajar Sains Siswa pada Siklus II

\begin{tabular}{rrrl}
\hline Skor & Frekuensi & Persentase & Kategori \\
\hline $0-54$ & 0 & $0,00 \%$ & Sangat rendah \\
$55-64$ & 5 & $14,29 \%$ & Rendah \\
$65-79$ & 9 & $25,71 \%$ & Sedang \\
$80-89$ & 11 & $31,43 \%$ & Tinggi \\
$90-100$ & 10 & $28,57 \%$ & Sangat tinggi \\
\hline
\end{tabular}

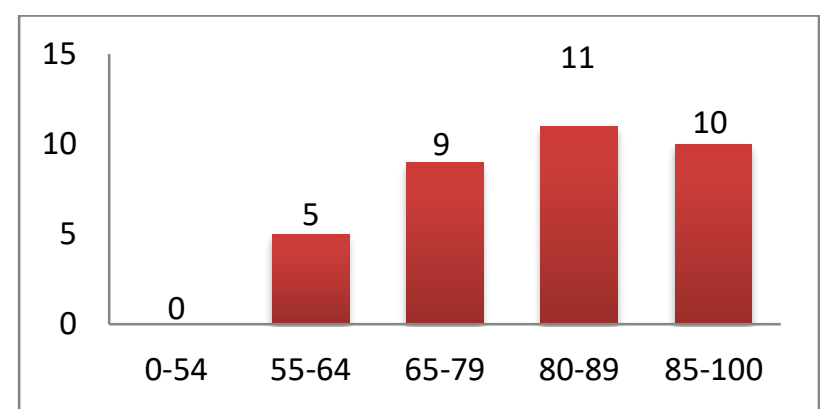

Gambar 2. Diagram Skor Hasil Belajar Sains Siklus II

Dari tabel tabel 4 dan gambar 2 di atas, menunjukkan bahwa hasil belajar sains siswa kelas VI SD Negeri 53 Sawerigading Kota Palopo sudah mengalami peningkatan yang cukup pesat,dan terlihat bahwa sudah tidak ada siswa yang berada pada kategori sangat rendah, dan 5 orang atau 14,29\%, kategori rendah, 9 orang atau 25,71\% berada pada kategori sedang, 11 orang atau $31,43 \%$ berada pada kategori tinggi dan 10 orang atau $28,57 \%$ berada pada kategori sangat tinggi.

Berdasarkan tabel 3 dan tabel 4 dan gambar 2 dapat disimpulkan bahwa hasil belajar sains siswa kelas VI SD Negeri 53 Sawerigading Kota Palopo setelah diterapkan model pembelajaran generatif pada siklus II berada dalam kategori "tinggi" dengan skor rata-rata 81,14 , skor maksimum 100 dan skor minimum 60. 


\section{Hasil Observasi Siswa}

Berdasarkan hasil observasi selama berlangsungnya penelitian dari siklus I dan siklus II tercatat sejumlah perubahan. Perubahan yang terjadi pada sikap siswa terhadap bahan pelajaran sains konsep perubahan lingkungan. Perubahan tersebut merupakan data yang diperoleh dari lembar observasi pada setiap pertemuan yang dicatat oleh guru selama penelitian.

\section{Siklus I}

Pada siklus I, proses pembelajaran dengan menggunakan model pembelajaran generatif, siswa belum bisa mengikuti pembelajaran dengan baik. Hal ini disebabkan siswa belum terbiasa dan masih bingung dengan pendekatan pembelajaran yang digunakan. Hasil observasi siswa pada siklus I adalah sebagai berikut:

1. Siswa yang memperhatikan penjelasan materi dalam proses belajar mengajar sebesar $71,42 \%$.

2. Siswa yang bertanya mengenai materi pelajaran yang belum dimengerti sebesar $18,75 \%$.

3. Siswa yang aktif pada saat mengerjakan soal-soal latihan dan melaksanakan percobaan sebesar $81,43 \%$.

4. Siswa yang melakukan kegiatan lain pada saat proses belajar mengajar sebesar $30 \%$.

5. Siswa yang meminta bimbingan guru dalam menyelesaikan soal-soal latihan maupun ketika melaksanakan percobaan sebesar $41,43 \%$.

6. Siswa yang mengumpulkan tugas atau pekerjaan rumah (PR) sebesar $88,57 \%$.

Siklus II

Setelah siklus I berakhir dan dilanjutkan dengan siklus II, siswa tidak lagi menempatkan ketegangan dalam proses belajar dengan penerapan model pembelajaran generative, baik itu pada saat pembelajaran berlangsung maupun pada saat pemberian PR. Adapun hasil observasi siswa pada siklus II adalah sebagai berikut:

1. Siswa yang memperhatikan penjelasan materi dalam proses belajar mengajar sebesar $90 \%$.

2. Siswa yang bertanya mengenai materi pelajaran yang belum dimengerti sebesar $30 \%$.

3. Siswa yang aktif pada saat mengerjakan soal-soal latihan dan melaksanakan percobaan sebesar $90,66 \%$.

4. Siswa yang melakukan kegiatan lain pada saat proses belajar mengajar sebesar $14,28 \%$.

5. Siswa yang meminta bimbingan guru dalam menyelesaikan soal-soal latihan maupun ketika melaksanakan percobaan sebesar $22,86 \%$.

Siswa yang mengumpulkan tugas atau pekerjaan rumah (PR) sebesar 98,57\%.

\section{Pembahasan}

\section{Hasil Belajar Siswa Pada Siklus I}

Dari hasil belajar siswa pada siklus I dan dianalisis maka persentase ketuntasan belajar siswa pada siklus I dapat dilihat pada berikut:

Tabel 5. Ketuntasan Belajar Siswa Pada Siklus I

\begin{tabular}{rrrl}
\hline Skor & Frekuensi & Persentase & Kategori \\
\hline $0-64$ & 13 & $37,14 \%$ & Tidak tuntas \\
$65-100$ & 22 & $62,86 \%$ & Tuntas \\
\hline
\end{tabular}


Tabel 5 menunjukkan bahwa 22 orang siswa atau $62,86 \%$ berada dalam kategori tuntas dan $17,14 \%$ siswa berada dalam kategori tidak tuntas dengan jumlah siswa sebanyak 13 orang memerlukan bimbingan khusus, perhatian dan motivasi, dalam hal ini akan dilaksanakan pembelajaran pada siklus II.

\section{Hasil Belajar Siswa Pada Siklus II}

Dari hasil belajar siswa pada siklus II dan dianalisis maka persentase ketuntasan belajar siswa pada siklus II dapat dilihat pada berikut:

Tabel 6. Ketuntasan Belajar Siswa Pada Siklus II

\begin{tabular}{rrrl}
\hline Skor & Frekuensi & Persentase & Kategori \\
\hline $0-64$ & 5 & $14,29 \%$ & Tidak tuntas \\
$65-100$ & 30 & $85,71 \%$ & Tuntas \\
\hline
\end{tabular}

Tabel 6 di atas dilihat bahwa siklus II dengan persentase ketuntasan belajar siswa sebesar $85,71 \%$ dengan kata lain 30 siswa termasuk dalam kategori siswa yang tuntas belajar dan tuntas secara klasikal karena rata-rata ketuntasan siswa kelas VI SD Negeri 53 Sawerigading yaitu $85,71 \%$ dan syarat klasikal yaitu $85 \%$ berarti sudah melebihi syarat klasikal. Sedangkan $14,29 \%$ dengan kata lain 7 siswa termasuk dalam kategori tidak tuntas. Jika dibandingkan dengan persentase ketuntasan belajar dari siklus I ke siklus II yaitu 62,86\% menjadi $85,71 \%$.

Selanjutnya tabel 7 di bawah ini memperlihatkan hasil belajar sains konsep perubahan lingkungan siswa kelas VI SD Negeri 53 Sawerigading Kota Palopo setelah diterapkan model pembelajaran generatif pada siklus I dan siklus II.

Tabel 7. Frekuensi dan Persentase Skor Hasil Belajar Siswa Pada Akhir Siklus I dan II

\begin{tabular}{lrrrrrl}
\hline \multirow{2}{*}{ No. } & \multirow{2}{*}{ Skor } & \multicolumn{2}{c}{ Frekuensi } & \multicolumn{2}{c}{ Persentase } & \multirow{2}{*}{ Kategori } \\
\cline { 3 - 6 } & & Siklus I & Siklus II & Siklus I & Siklus II & \\
\hline 1. & $0-54$ & 8 & 0 & $22,85 \%$ & $0 \%$ & Sangat rendah \\
2. & $55-64$ & 5 & 5 & $14,29 \%$ & $14,29 \%$ & Rendah \\
3. & $65-79$ & 15 & 9 & $42,86 \%$ & $25,71 \%$ & Sedang \\
4. & $80-89$ & 7 & 11 & $20,00 \%$ & $31,43 \%$ & Tinggi \\
5. & $90-100$ & 0 & 10 & $0,00 \%$ & $28,57 \%$ & Sangat tinggi \\
\hline
\end{tabular}

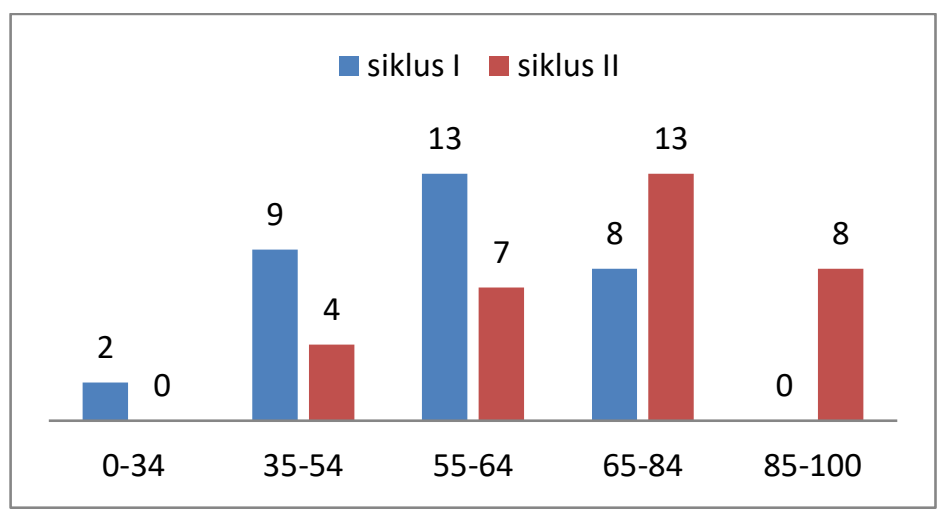

Gambar 3. Diagram Perbandingan Skor Hasil Belajar Sains Siklus I dan II

Peningkatan skor rata-rata hasil belajar sains konsep perubahan lingkungan siswa kelas VI SD Negeri 53 Sawerigading Kota Palopo pada siklus I dan II adalah sebagai berikut. 


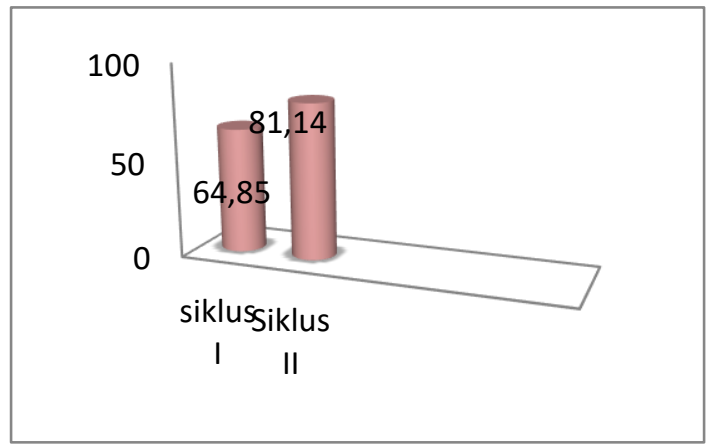

Gambar 4. Diagram Skor Rata-Rata Hasil Belajar Sains Siklus I dan II

Pada gambar di atas, terlihat jelas peningkatan hasil belajar dari siklus I ke siklus II sebesar 16,29. Hal ini dapat dilihat dari skor rata-rata hasil belajar sains konsep perubahan lingkungan dimana rata-rata hasil belajar siswa pada siklus I adalah 64,85 dan siklus II adalah 81,14.

\section{Hasil Observasi Siswa}

Dari hasil observasi yang dilakukan selama 2 siklus dengan menerapkan model pembelajaran generatif memberi banyak perubahan pada siswa, antara lain:

1. Siswa lebih termotivasi untuk belajar.

2. Keberanian siswa untuk menyelesaikan soal dengan sendiri meningkat. Hal ini ditunjukkan dengan meningkatnya jumlah siswa yang mampu menyelesaikan soal-soal yang diberikan.

3. Rasa percaya diri siswa meningkat dan semakin bertambahnya siswa yang berani tampil untuk mengerjakan soal di depan kelas.

4. Mengubah paradigma mengajar menjadi paradigm belajar.

5. Meningkatnya keaktifan dan memotivasi siswa untuk belajar kelompok.

Di awal pertemuan banyak kendala yang dihadapi antara lain siswa masih bingung dalam pembelajaran sains dengan model pembelajaran generatif, ini berlangsung sampai akhirnya pelaksanaan siklus I. Maka perbaikan dilaksanakan untuk membenahi pada pelaksanaan siklus II dengan mengacu pada siklus I.

Pada siklus II kendala-kendala yang ditemukan di Siklus I sudah teratasi. Perubahanperubahan yang terjadi dari Siklus I ke siklus II antara lain:

Tabel 8. Persentase Keaktifan Siswa Pada Siklus I dan II

\begin{tabular}{|c|c|c|c|c|c|c|c|c|c|}
\hline \multirow[t]{2}{*}{ No. } & \multirow[t]{2}{*}{ Komponen Yang Diamati } & \multicolumn{2}{|c|}{$\begin{array}{l}\text { Siklus I } \\
\text { Pertemuan }\end{array}$} & & \multirow[t]{2}{*}{$\%$} & \multicolumn{3}{|c|}{$\begin{array}{l}\text { Siklus II } \\
\text { Pertemuan }\end{array}$} & \multirow[t]{2}{*}{$\%$} \\
\hline & & 1 & 2 & 3 & & 1 & 2 & 3 & \\
\hline 1 & $\begin{array}{l}\text { Siswa yang memperhatikan materi } \\
\text { pelajaran }\end{array}$ & 22 & 28 & & 71,42 & 28 & 35 & & 90,00 \\
\hline 2 & $\begin{array}{l}\text { Siswa yang bertanya mengenai } \\
\text { materi pelajaran yang belum } \\
\text { dimengerti }\end{array}$ & 9 & 12 & T & 30,00 & 5 & 8 & $\begin{array}{l}T \\
E \\
S\end{array}$ & 18,57 \\
\hline 3 & $\begin{array}{l}\text { Siswa yang aktif pada saat } \\
\text { melaksanakan percobaan }\end{array}$ & 27 & 30 & S & 81,43 & 33 & 35 & $S$ & 90,66 \\
\hline 4 & $\begin{array}{l}\text { Siswa yang melakukan kegiatan lain } \\
\text { pada saat proses belajar mengajar }\end{array}$ & 12 & 9 & $\begin{array}{l}\text { l } \\
K\end{array}$ & 30,00 & 8 & 2 & $\begin{array}{l}\text { I } \\
K\end{array}$ & 14,28 \\
\hline 5 & $\begin{array}{l}\text { Siswa yang meminta bantuan guru } \\
\text { ketika menyelesaikan soal maupun } \\
\text { ketika percobaan dilaksanakan }\end{array}$ & 15 & 14 & L & 41,43 & 10 & 6 & $\begin{array}{l}L \\
U \\
S\end{array}$ & 22,86 \\
\hline 6 & $\begin{array}{l}\text { Siswa yang mengumpulkan tugas } \\
\text { atau PR }\end{array}$ & 30 & 32 & & 88,57 & 35 & 34 & II & 98,57 \\
\hline
\end{tabular}


1. Pada siklus I, persentase siswa yang memperhatikan penjelasan guru dalam proses belajar mengajar sebesar $71,42 \%$ sedangkan pada siklus II naik menjadi $90 \%$.

2. Pada siklus I, siswa yang bertanya mengenai materi pelajaran yang belum dimengerti sebesar $30 \%$, sedangkan pada Siklus II menurun menjadi $18,57 \%$. Ini berarti tingkat pemahaman siswa tentang materi yang dibahas semakin meningkat.

3. Siswa yang aktif dalam mengerjakan soal-soal latihan dan percobaan yang diberikan pada siklus I sebesar $81,43 \%$, sedangkan pada siklus II meningkat menjadi 90,66\%.

4. Persentase siswa yang melakukan kegiatan lain pada saat proses belajar mengajar guru sebesar $30 \%$ pada Siklus I dan berkurang pada Siklus II menjadi $14,28 \%$

5. Siswa yang meminta bimbingan guru dalam menyelesaikan soal-soal latihan maupun ketika percobaan berlangsung pada siklus I sebesar 41,43\%, sedangkan pada siklus II sebesar $22,86 \%$.

6. Siswa yang mengumpulkan tugas/PR pada siklus I sebesar $88,57 \%$, pada siklus II meningkat menjadi $98,57 \%$.

\section{Refleksi Siklus I}

Pada siklus I dibagi dalam tujuh kelompok dimana tiap kelompok ada yang terdiri dari 5 orang dari 35 siswa. Pembagian anggota kelompok dipilih secara acak. Pada awalnya sebagian cenderung tidakpuas dengan pembagian kelompok tersebut karena mereka menginginkan teman kelompoknya yang sudah akrab dengan teman mereka, tetapi ada juga dari mereka kelompoknya yang sudah akrab dengan mereka, tetapi ada juga dari mereka yang merasa senang dalam pembagian kelompok secara acak, supaya mereka lebih akrab dengan teman yang lain. Sebagian siswa lebih suka belajar kelompok karena saling membantu, apabila menemukan kesulitan pada saat mengerjakan soal tanpa harus bertanya pada guru.

Pada pertemuan pertama pelaksanaan Siklus I, sebagai tugas kelompok siswa diminta untuk membahas lembar kegiatan siswa yang telah disediakan. Pada umumnya antusias dan keaktifan siswa dalam proses belajar mengajar dalam menjawab pertanyaan guru bertanya tentang materi yang dibahas, serta mengerjakan soal/tugas dapat dikatakan tidak ada. Hal tersebut hanya dilakukan oleh siswa yang tergolong pintar. Serta mencatat saja tiap materi yang diajarkan.

Pembelajaran pada siklus I secara umum siswa belum mampu menemukan masalahmasalah kontekstual yang berkaitan dengan materi yang diajarkan dan belum mampu mengkonstruksi sendiri pengetahuannya. Pada pertemuan kedua hingga akhir siklus I, antusias siswa untuk menyelesaikan tugas secara berkelompok mulai tampak, walaupun masih ada siswa yang pasif, hal ini terlihat dari kurangnya komunikasi.

\section{Refleksi Siklus II}

Siklus II peneliti sedikit mengalami kesatuan para pertemuan pertama, yaitu dalam pembentukan kelompok, karena siswa tidak inin anggota kelompoknya diubah. Namun, pada pertemuan berikutnya antusias antara sesama anggota kelompoknya dalam proses belajar mengajar sudah mengalami peningkatan.

Siklus II antusias siswa semakin memperlihatkan kemajuan. Hal ini ditandai dengan jumlah siswa yang menjawab pertanyaan guru, bertanya tentang materi dan mengajukan diri untuk mengerjakan, mampu mengemukakan masalah-masalah kontekstual yang berhubungan dengan materi pelajaran dan siswa yang mampu mengkonstruksi sendiri pengetahuannya juga mengalami peningkatan. 
Kerja sama antara anggota kelompok meningkat, dilihat seperti siswa yang ditunjuk dapat mewakili kembali kelompoknya mengerjakan soal papan tulis, dapat mengerjakan soal dengan cepat dan benar, serta tutor yang antusias membimbing teman sekelompoknya. Secara umum dikatakan bahwa seluruh kegiatan pada siklus II mengalami peningkatan bila dibandingkan siklus I.

Hasil analisis kualitatif terlihat bahwa pada dasarnya penerapan model pembelajaran generatif, siswa sudah merasa tidak malu untuk meminta bimbingan kepada guru. Pada siklus I salama kegiatan proses belajar mengajar berlangsung. Terlihat pada siswa sudah memulai termotivasi untuk mengikuti pelajaran sains disebabkan adanya kerja kelompok dan konteks yang dibicarakan tidak jauh dari apa yang mereka ketahui. Hal ini disebabkan karena model dan pendekatan ini baru diterapkan dalam proses pembelajaran sains pada siswa kelas VI SD Negeri 53 Sawerigading Kota Palopo, setelah diterapkan model pembelajaran generatif. Setelah diadakan tes siklus I terlihat adanya peningkatan hasil belajar sains serta antusias belajar yang mana skor rata-rata yang dicapai siswa berada pada kategori sedang.

Setelah dilaksanakan refleksi kegiatan pada siklus I, maka dilakukan beberapa perbaikan kegiatan yang dianggap perlu demi peningkatan hasil belajar siswa pada siklus II. Pada siklus I terlihat bahwa antusias siswa untuk belajar mengalami peningkatan, dimana siswa yang sebelumnya mengharapkan bimbingan guru, siswa tersebut telah mampu berusaha sendiri untuk memecahkan masalahnya.

Selain itu dapat dilihat dari jumlah kehadiran, sudah mulai aktif bertanya dan menjawab pertanyaan guru demi keberhasilan kelompoknya. Juga siswa merasa senang dan nyaman ketika mereka diberi kesempatan untuk mengemukakan masalah-masalah kontekstual yang berhubungan dengan materi pelajaran. Siswa yang mampu mengkonstruksi sendiri pengetahuannya sudah mengalami kemajuan.

Hal ini disebabkan karena komunikasi antara siswa sudah ada atau terjalin. Setelah diberikan tes siklus II, skor rata-rata yang dicapai berada pada kategori tinggi. Jika dibandingkan pada siklus I, maka dapat disimpulkan bahwa model pembelajaran generatif dapat meningkatkan hasil belajar sains siswa kelas VI SD Negeri 53 Sawerigading Kota Palopo

\section{Kesimpulan}

Hasil belajar siswa mengalami peningkatan dari siklus I ke siklus II dimana pada siklus I siswa yang tuntas hasil belajarnya sebanyak 22 orang dari 35 siswa dengan rata-rata skor akhir sebesar 64,85 dan tergolong dalam kategori sedang. Sedangkan pada siklus II siswa yang mengalami ketuntas hasil belajar sebanyak 30 orang dari 35 siswa dengan skor sebesar 81,14 dan tergolong tinggi. Terjadinya peningkatan persentase keaktifan siswa dari siklus I ke siklus II keaktifan dalam proses belajar mengajar, pelaksanaan percobaan sains atau pengerjaan LKS yang membuktikan bahwa model pembelajaran generative sesuai untuk diterapkan dalam pembelajaran sains.

Dari hasil yang diperoleh, maka peneliti mengajukan beberapa saran dalam upaya peningkatan mutu Pendidikan, yaitu guru, khususnya pada guru sains, diharapkan agar menerapkan model pembelajaran generatif untuk meningkatkan kemampuan menyelesaikan masalah-masalah dan memicu siswa agar lebih aktif dan kreatif dalam proses belajar mengajar. Meskipun demikian, perlu penelitian lebih lanjut dengan pokok bahasan yang sama yaitu perubahan lingkungan dengan model pembelajaran yang lain seperti tipe STAD, Jigsaw, dan lain-lain. Sehingga dapat dibandingkan metode mana yang cocok dalam mengajarkan 
konsep perubahan lingkungan pada siswa kelas VI SD Negeri 53 Sawerigading Kota Palopo pada pokok konsep listrik dinamis.

\section{Referensi}

Arikunto, S., Shuardjono, \& Supriadi. (2009). Penelitian Tindakan Kelas. Jakarta: PT. Bumi Aksara.

Angora, T. (2007). Metode Penelitian. Jakarta: Universitas Terbuka.

Asep, J. (2008). Evaluasi Pembelajaran. Yogyakarta: Multi Pressindo.

Djaali. (2008). Psikologi Pendidikan. Jakarta: PT. Bumi Aksara.

Khaeruddin, E. (2006). Metodologi Penelitian. Makassar: Berkah Utami Makassar.

Mulyasa. (2006). Menjadi Guru Profesional Menciptakan Pembelajaran yang Kreatif dan Menyenangkan. Bandung: Rosdakarya Bandung.

Mustaqim. (2008). Psikologi Pendidikan. Semarang: Pustaka Pelajar Offset Semarang.

Yatim, R. (2009). Paradigma Baru Pembelajaran; Sebagai Referensi bagi Pendidik dalam Implementasi Pembelajaran yang Efektif dan Berkualitas. Jakarta: Kencana Prenada media Group.

Sudjana, N. (2005). Penelitian Hasil Proses Belajar Mengajar. Bandung: Remaja Rosdakarya. Slameto. (2003). Belajar dan Faktor-Faktor yang Mempengaruhinya. Jakarta: PT. Rineka Cipta.

Wena, M. (2009). Strategi Pembelajaran Inovetif Kontemporer (Suatu Tinjauan Konseptual Operasional). Jakarta: Bumi Aksara. 